\title{
IMPLEMENTASI E-GOVERNMENT DALAM UPAYA PENINGKATAN PELAYANAN BERBASIS ONLINE DI KABUPATEN KULON PROGO
}

\author{
Aina Shafira1), Ardita Kurniasiwi2) \\ 12 Program studi Ilmu Pemerintahan, Fakulitas Ilmu sosial dan Ilmu Politik, \\ Universitas Muhammadiyah Yogyakarta.
}

\begin{abstract}
Abstrak
E-Government sebagai suatu mekanisme baru dalam interaksi antara pemerintah dan masyarakat, dalam pemanfaatan teknologi informasi terutama internet harus dapat memperbaiki layanan kepada masyarakat. Dengan adanya EGoverment yang telah disediakan oleh pemerintah kulon progo melalui pelayanan berbasis online, maka dapat dianalisis bagaimana implementasi e-government dalam meningkatkan pelayanan publik di Kabupaten Kulon progo sebagaimana yang telah dikembangkan sedemikian rupa dalam upaya inovasi peningkatan pelayanan di kabupaten kulon progo yang efektif dan efisien. Penelitian ini menggunakan metode kualitatif. Data yang digunakan dalam penelitian ini bersumber dari data sekunder, dengan Metode yang berasal dari dokumentasi yang dimana data diperoleh dari berbagai macam sumber literatur sebelumnya yaitu web resmi instansi dan jurnal-jurnal untuk keabsahan penelitian. Aplikasi eGoverment di Kabupaten Kulon Progo bertujuan untuk meningkatkan efisiensi dan keterpaduan penyelenggaraan SPBE, namun perkembangan SPBE tersebut masih dalam proses pengintregasian. Implementasi e-government di kabupaten kulon progo bisa dikatakan belum efektif karena Pemkab Kulon progo kurang dalam penggunaan aplikasi dibanding pemda-pemda lain di Daerah Istimewa Yogyakarta. Namun Dengan adanya pemeriksaan kinerja pendahuluan Sistem Pemerintahan Berbasis Elektronik (SPBE) diharapkan dapat meningkatkan penggunaan aplikasi sehingga pelayanannya bisa tepat dan memudahkan dalam pengelolaan keuangan, sehingga bisa tepat waktu dan akurat.
\end{abstract}

Kata kunci: Implementasi, E-Government, Pelayanan

\begin{abstract}
E-Government as a new mechanism for interaction between government and society, in the use of information technology, especially the internet, must be able to improve services to the public. With the existence of E-Government that has been provided by the Kulon Progo government through online-based services, it can be analyzed how the implementation of e-government in improving public services in Kulon Progo Regency as it has been developed in such a way as to make an effort to improve services in an effective Kulon Progo Regency. and efficient. This study uses a qualitative method. The data used in this study are sourced from secondary data, with a method derived from documentation where the data is obtained from various previous literature sources, namely the official website of the agency and journals for the validity of the study. The e-Government application in Kulon Progo Regency aims to improve efficiency and integration of SPBE implementation, but the development of $S P B E$ is still in the process of integration. The implementation of e-government in Kulon Progo district can be said to be ineffective because the Kulon Progo Regency Government is less in using the application than other regional governments in Daerah Istimewa Yogyakarta. However, with the preliminary performance inspection
\end{abstract}


of the Electronic Based Government System (SPBE) it is hoped that it can increase the use of applications so that services can be precise and facilitate financial management, so that they can be timely and accurate.

Keywords: Implementation, E-Government, Service

\section{PENDAHULUAN}

Salah satu tanggung jawab pemerintah adalah memberikan pelayanan yang berkualitas kepada masyarakat karena saat ini pelayanan publik di Indonesia cenderung kurang sehingga masyarakat Indonesia mulai memiliki rasa hilang kepercayaan terhadap pemerintah sebagai birokrasi publik. Sebagian besar masyarakat kurang mendapatkan informasi, kebingungan dalam mendapatkan prosedur pelayanan, bahkan mengalami keterbatasan sarana dan prasarana pelayanan publik. Selain itu cara pelayanan yang diterima oleh masyarakat sering direndahkaan martabatnya sebagai warga negara. Dalam posisi ini, masyarakat merupakan klien yang membutuhkan bantuan birokrasi pemerintah, sehingga masyarakat harus menaati peraturan birokrasi dan keinginan instansi pemerintah.Menurut (Indonesia, 2009) tentang Pelayanan Publik menjelaskan bahwa memberikan pelayanan yang bermutu tinggi berdasarkan prinsip dan tujuan pelayanan, dan fungsi utama pemerintahan yang baik yaitu mampu menyediakan kebutuhan pelayanan bagi setiap warga negara dan penduduk sesuai dengan peraturan perundangundangan,termasuk barang,jasa,dan / atau jasa administrasi.

Perkembangan teknologi informasi dan komunikasi berkembang sangat pesat,baik dalam mencari informasi maupun menerima informasi,meneliti dan memperoleh informasi yang dibutuhkan secara efektif kapanpun dan dimanapun.Kehadiran internet dalam mengakses teknologi informasi dan komunikasi memudahkan semua aktivitas dalam perolehan dan komunikasi informasi yang tepat.Menurut (Presiden et al., 2003) Teknologi informasi dan komunikasi juga mencakup semua golongan masyarakat,termasuk pemerintah.Teknologi informasi dan komunikasi digunakan dalam pengembangan pembangunan kota pintar,salah satunya 
adalah aplikasi untuk meningkatkan efisiensi,meningkatkan layanan publik,dan meningkatkan kesejahteraan warga negara.

Salah satu teknologi Informasi yang sangat berpengaruh pada kehidupan manusia, khususnya di Indonesia adalah penerapan electronic government (e-government). E-Government dalam hal ini adalah mengacu pada pendistribusian informasi dan layanan kepada orang atau perusahaan atau departemen pemerintah lainnya oleh pemerintah nasional atau lokal melalui Internet atau sarana digital lainnya. E-Government adalah kata umum untuk layanan berbasis web lokal, negara bagian, dan federal. Egovernment adalah proses penggunaan teknologi informasi dan komunikasi untuk meningkatkan efisiensi, efektivitas, transparansi, dan akuntabilitas pemerintah yang saat ini fokus di Indonesia pada implementasi egovernment. Upaya Meningkatkan Perubahan Kemajuan dalam penerapan e-government terjadi pada April 2004 ketika pemerintah mengajukan permohonan untuk seluruh WNI, paspor, SIM, dan nomor pajak dengan satu nomor identifikasi (SIN). Penilai difokuskan pada keberadaan web, interaksi, transaksi, dan transisi, keberlanjutan, kemauan dan transparansi e-Government, nilai investasi di setiap wilayah, kepemimpinan, pelembagaan e-government di sektor-sektor ini, proses manajemen, kinerja kepemimpinan kantor depan, dan faktor anggaranPenerapan e-government di Indonesia sudah mengalami kemajuan yang sangat pesat, dibandingkan ketika implementasi awal pertama kali. Menyadari negara Indonesia masih tergolong negara berkembang, maka pada implemetasi nyata pelaksanaan e-government masih mengalami berbagai macam kendala. Mengingat implementasi e-government memerlukan berbagai macam persiapan seperti biaya yang besar, sumber daya manusia berkualitas, program kerja yang jelas, waktu implementasi yang cukup lama serta beresiko terhadap kegagalan, dan yang peling penting adalah soalilasi yang efektif untuk menagajak keterlibatan masyarakat dalam mendukung opersional program kerja pemerintah.

E-government Indonesia diperkenalkan pada tahun 2001 tentang pengembangan telekomunikasi,media,dan informatika melalui Peraturan 
Presiden Nomor 6 Tahun 2001. Perjanjian ini mewajibkan instansi pemerintah untuk mewujudkan pemerintahan yang baik melalui pemanfaatan teknologi telekomunikasi,media,dan informatika. Hal ini bertujuan untuk meningkatkan hubungan kerja antar instansi pemerintah untuk meningkatkan, memberikan, mampu meningkatkan pelayanan publik, serta meningkatkan efisiensi dan efektivitas sosial. fenomena Electronic Government (e-Government) terus-menerus menuntut instansi pemerintahan untuk memastikan bahwa harus ada transformasi operasional di bidang pelayanan publik. Transformasi ini bukanlah pekerjaan mudah. Butuh perencanaan yang matang, konsultasi intensif dengan IT konsultan, jajak pendapat di masyarakat, penyuluhan publik, hingga kontrol pelaksanaan. Dengan kompleksnya proses tersebut, nyatanya sampai hari ini masih ada saja urusan birokrasi yang berbelitbelit. Namun, kita juga tidak bisa menafikkan fakta bahwa sudah ada banyak instansi pemerintahan yang melakukan reformasi birokrasi berkat implementasi e-Government. e-Government ini tidak hanya berjalan di satudua instansi, tetapi di seluruh instansi yang ada. Ketika sudah terlaksana, akan hadir sistem yang akurat dan terintegrasi. Di Indonesia sudah ada banyak kabupaten/kota yang menerapkan e-Government dengan cukup baik. Salah satunya ada di Daerah Istimewa Yogyakarta. pada 2016, Menteri Pendayagunaan Aparatur Negara dan Reformasi Birokrasi (PAN-RB) menyebut bahwa DIY secara umum akan dijadikan percontohan di tingkat nasional.

Di Yogyakarta sendiri, e-Government telah dijalankan dengan basis strategis pemanfaatan TI, keterlibatan publik dalam pengambilan keputusan, serta sistem administrasi kependudukan dan sistem administrasi perizinan. Kabupaten Kulon Progo merupakan salah satu daerah yang terpilih untuk menerapkan e-government dan smart city di Indonesia. Salah satu kota pintar di Kabupaten Kulon Progo merupakan wujud implementasi teknologi informasi dan komunikasi. Dalam rangka implementasi e-government di Kabupaten Kulon Progo, telah dikeluarkan Peraturan Kabupaten Kulon Progo No. 101 Tahun 2017 tentang Penerapan 
e-Government Tahun dalam rencana strategis implementasi e-government terkait dengan kepentingan aparatur daerah, masyarakat,dan pemangku kepentingan, instansi pemerintah di bidang komunikasi dan informatika selaras.Teknologi informasi dan komunikasi (TIK) telah mengubah proses, operasi, dan struktur sektor publik di negara maju maupun berkembang (Wulansari \& Inayati, 2019). Penerapan TIK dalam penyelenggaraan pemerintahan dianggap sebagai solusi hemat biaya yang dapat meningkatkan komunikasi antara instansi pemerintah dan konstituen mereka.Kabupaten Kulon Progo melakukan kolaborasi dengan Dinas Komunikasi dan Informatika.Pemerintah Daerah Kulon Progo juga telah membentuk komite TIK yang beranggotakan pemerintah, akademisi, praktisi dan masyarakat (Alwafi Ridho Subarkah, 2018).Komite TIK sendiri bertugas sebagai memberikan masukan dalam perumusan kebijakan umum pengembangan, pengkajian serta masukan dalam rangka pengembagan TIK seperti infastruktur,aplikasi,dan konten menuju pembangunan Smart City.Kabupaten Kulon Progo juga mengeluarkan program Quick Win sebagai inovasi dalam menerapkan e-government. Quick Win sendiri yaitu merupakan sebuah bagian dari modul pendukung dari smart city di Kulon Progo.

E-Government sebagai suatu mekanisme baru dalam interaksi antara pemerintah dan masyarakat, dalam pemanfaatan teknologi informasi terutama internet harus dapat memperbaiki layanan kepada masyarakat. Dengan adanya E-Goverment yang telah disediakan oleh pemerintah kulon progo melalui pelayanan berbasis online, maka dapat dianalisis bagaimana implementasi e-government dalam meningkatkan pelayanan publik di Kabupaten Kulon progo sebagaimana yang telah dikembangkan sedemikian rupa dalam upaya inovasi peningkatan pelayanan di kabupaten kulon progo yang efektif dan efisien.

\section{METODE PENELITIAN}

Penelitian ini menggunakan metode kualitatif yang bertujuan mendeskripsikan implementasi E-Government dalam upaya peningkatan 
pelayanan berbasis online di Kabupaten Kulon Progo. Kebijakan Pemkab melaksanakan konsep E-Government ditunjukkan dengan inovasi kinerja melalui sistem online sebagai objek penelitian. Data yang digunakan dalam penelitian ini bersumber dari data sekunder yaitu dari studi literatur beberapa dokumen terkait dengan pembahasan topik (Kurniawan \& Atmojo, 2020). Metode yang diambil berasal dari dokumentasi yang dimana data diperoleh dari berbagai macam sumber literatur sebelumnya yaitu web resmi instansi dan jurnal-jurnal untuk keabsahan penelitian.

\section{PEMBAHASAN}

Penerapan e-Government ditargetkan untuk mewujudkan tata kelola pemerintahan yang baik dan bersih Melalui pemanfaatan TIK secara efektif di kalangan aparatur pemerintahan. Menurut (Nugraha, 2018) Di tingkat nasional, sudah banyak pemerintah daerah yang yang memiliki inisiatif untuk mengimplementasikan e-government. Meski demikian, kondisi di lapangan menemukan perbedaan yang terjadi antar daerah dengan berbagai alasan, seperti faktor keterbatasan anggaran, infrastruktur dan sumber daya manusia yang berbeda-beda.Persamaan penelitian antara Nugraha dengan peneliti yaitu sama-sama membahas tentang e-government dan pelayanan publik.Sedangkan perbedaannya yaitu penelitian Nugraha membahas tentang elemen sukses pengembangan e-government di pemerintah kabupaten sleman, sedangkan peneliti membahas tentang bagaimana implementasi e-government berbasis online yang dilaksanakan di Kabupaten Kulon Progo.

Menurut (Sosiawan, 2008) pemanfaatan e-government di indonesia dikarenakan adanya perubahan kehidupan berbangsa dan bernegara secara fundamental, dari sistem kepemerintahan yang otoriter dan sentralistik menuju ke sistem kepemerintahan yang demokratis, dan menerapkan perimbangan kewenangan pusat dan daerah otonom. Perubahan yang tengah terjadi tersebut menuntut terbentuknya kepemerintahan yang bersih, transparan, dan mampu menjawab tuntutan perubahan secara efektif. Persamaan penelitian antara sosiawan dengan peneliti yaitu sama-sama membahas faktor penghambat 
implementasi e-government.Sedangkan perbedaanya peneliti sosiawan melakukan penelitian faktor penghambat implementasi e-government di seluruh Indonesia dan peneliti hanya meneliti di satu daerah yaitu kabupaten kulon progo.

Namun realisasi pengembangan e-government di Indonesia menghadapi banyak tantangan baik dalam hal geografi,ekonomi,teknologi,politik,maupun budaya. Menurut (Sari \& Winarno, 2012) dalam proses implementasi, ditemukan beberapa fenomena yang menunjukkan implementasi e-government masih berjalan lambat dan tidak signifikan dengan besarnya biaya yang dikeluarkan Negara. Kesenjangan antar daerah,dan adanya duplikasi database menjadikan data produk pemerintah cenderung kurang dipercaya. Persamaan penelitian antara sari \& winarno dengan peneliti yaitu samasama meneliti tentang implementasi e-government system, sedangkan perbedaanya peneliti sari \& winarno meneliti implementasi e-government system di seluruh Indonesia namun peneliti hanya meneliti di satu daerah yaitu kabupaten kulon progo.

Menurut (Wulansari \& Inayati, 2019) masyarakat merupakan pemegang kepentingan utama dalam penyelenggaraan e-government. Namun demikian, dalam konteks penelitian e-government, orientasi terhadap masyarakat masih belum banyak dieksploitasi karena sebagian besar proyek e-government hanya mentransformasi layanan dan informasi yang semula masih tradisional menjadi menggunakan teknologi. Model-model penilaian kematangan e-government yang sudah ada pun sebagian besar hanya mengukur kemampuan teknologi egovernment. Persamaan penelitian antara wulan sari\&inayati dengan peneliti yaitu melihat tingkat kematangan implementasi e-government untuk masyarakat. Sedangkan perbedaan penelitian antara wulansari \& inayati dengan peneliti yaitu melihat tingkat kematangan implementasi egovernment dari seluruh masyarakat indonesia dan masyarakat daerah.

Pengelolaan pemerintahan yang mengacu pada pengelolaan pemerintahan berbasis elektronik sudah merupakan kebutuhan yang 
tidak dapat dihindarkan oleh pemerintah. Pemanfaatan teknologi informasi pada pemerintahan bertujuan untuk mendukung penyelenggaraan tata kelola organisasi yang 1 ebih baik, sehingga mampu menyediakan layanan informasi tepat guna bagi stakeholder. Layanan digitalisasi pemerintah dapat dilaksanakan melalui pemanfaatan internet. Persamaan penelitian antara peneliti dengan (Pratiwi \& Muslihudin, 2018) yaitu sama-sama penerapan government publik pada setiap SKPD berbasis pelayanan. Sedangkan perbedaannya yaitu berada di lokasi penelitiannya.

E-Government memiliki 4 tahapan perkembangan implementasi Indonesia, yang pertama web presence, yaitu memunculkan website daerah di internet. Dalam tahap ini, informasi dasar yang dibutuhkan masyarakat ditampilkan dalam website pemerintah.Kedua Interaction, yaitu web daerah yang menyediakan fasilitas interaksi antara masyarakat dan Pemerintah Daerah. Dalam tahap ini, informasi yang ditampilkan lebih bervariasi, seperti fasilitas download dan komunikasi E-mail dalam website pemerintah. Ketiga Transaction, yaitu web daerah yang selain memiliki fasilitas interaksi juga dilengkapi dengan fasilitas transaksi pelayanan publik dari pemerintah. Dan keempat Transformation, yaitu dalam hal ini pelayanan pemerintah meningkat secara terintegrasi.

Selain itu untuk menerapkan konsep-konsep digitalisasi pada sektor publik, ada tiga elemen sukses yang harus dimiliki dan diperhatikan dengan baik. Pertama unsur pendukung merupakan unsur terpenting dalam pengembangan e-government, dibutuhkan dukungan atau kemauan politik dari pejabat publik. Dengan cara ini, konsep e-government dapat diterapkan, dan berbagai rencana pengembangan dan pengembangan egovernment dapat dilaksanakan.Kedua,unsur capacity merupakan sumber daya yang dibutuhkan dalam pengembangan e-government, sehingga konsep yang dibuat dapat menjadi kenyataan. Namun unsur ini membutuhkan 3 sumberdaya yaitu sumber daya keuangan yang cukup untuk mengimplementasikan berbagai program e-government, ketersediaan infrastruktur teknologi informasi yang memadai merupakan 50\% kunci 
sukses implementasi e-government, dan tersedianya sumber daya manusia dengan kapabilitas dan keahlian yang dibutuhkan agar penerapan egovernment dapat memenuhi prinsip manfaat yang diharapkan. Ketiga unsur nilai didasarkan pada manfaat yang diperoleh pemerintah sebagai penyedia layanan dan masyarakat sebagai penerima e-government. Dalam menentukan apakah manfaat e-government adalah elemen nilai dari orang sebagai penerima layanan.

Berdasarkan hasil kajian sejumlah praktisi e-Government di berbagai negara, secara pokok ada tiga tantangan besar yang dihadapi oleh pemerintah maupun masyarakat dalam mengembangkan konsep eGovernment di antaranya yaitu tantangan Penentuan Kanal Akses, tantangan Keterlibatan Pihak Non-Pemerintah, dan tantangan Pembiayaan Manajemen Perubahan. Yang pertama, Jika dalam pelayanan yang menggunakan kanal akses tradisional, pemerintah hanya beroperasi selama jam kerja (8 jam sehari, kecuali Sabtu dan Minggu), maka dengan memanfaatkan fasilitas teknologi informasi yang ada, masyarakat dapat melakukan transaksi dan interaksi kapanpun masyarakat membutuhkannya. Dengan kalimat lain, kanal akses merupakan salah satu kunci sukses (key success factor) dalam pengembangan e-Government karena fungsinya sebagai antarmuka (interface) yang menghubungkan masyarakat dengan pemerintah (front office technology). Masalah yang dihadapi dalam hal ini adalah Jenis teknologi kanal akses apa saja yang harus dibangun sehingga dapat dipergunakan oleh masyarakat, Bagaimana agar keberadaannya dapat merata di seluruh wilayah negara sehingga dapat menyentuh setiap lapisan masyarakat, Strategi apa yang harus dijalankan agar masyarakat yang belum terbiasa dengan teknologi ini dapat memanfaatkannya. Yang kedua, Keberhasilan penerapan e-Government terletak juga pada keberhasilan penerapan konsep mixed economy. Yaitu sebuah konsep yang menyangkut bagaimana pemerintah membuka jalur kerja sama kepada kalangan institusi public, institusi swasta dan institusi non-komersial untuk bersama-sama beraliansi menciptakan pelayanan kepada masyarakat. Dalam membuka kerja sama macam ini, selain 
memerlukan sebuah pemahaman akan pelaksanaan sebuah paradigm baru, juga memiliki potensi negative yang jika tidak dikelola dengan baik akan berdampak buruk pada lingkungan pemerintahan. Yang ketiga, Merencanakan, mengembangkan, dan mengimplementasikan konsep eGovernment pada dasarnya adalah menjalankan sebuah perubahan manajemen (change management) yang kompleks. Seperti diketahui bersama, kebanyakan orang sangat anti dengan perubahan (people don't like to change). Oleh karena itu, dibutuhkan strategi perubahan yang baik dan efektif.

Kulon Progo menjadi salah satu daerah yang menerapkan EGovernment dalam memberikan pelayanannya kepada masyarakat secara online. salah satu aspek yang menjadi tujuan penerapan e-government adalah tersedianya sistem informasi yang dapat mendukung kegiatan dan pelayanan yang dilakukan oleh Pemerintah kulon progo. Keberadaan sistem informasi bertujuan untuk mengelola data dan informasi yang dimiliki oleh pemerintah guna mengembangkan sistem informasi tersebut guna memperoleh pelayanan yang lebih efektif dan efisien dalam proses birokrasi. Maka dari itu terdapat sistem informasi di lingkungan Pemerintah kulon progo yang bertujuan untuk mendukung proses birokrasi dengan sebaikbaiknya dan prosedur birokrasi dapat memanfaatkan potensi teknologi informasi dengan sebaik-baiknya untuk mendukung kelancaran pelaksanaan tugas dan pelayanan kepada Pemerintah kulon progo.

Menurut data website resmi Pemerintah Kulon Progo $^{1}$, layanan egovernment pemerintah Kabupaten Kulon Progo terdiri dari Aplikasi layanan pemerintah dan Aplikasi layanan publik. Pada aplikasi layanan publik terdiri dari Sistem pengadaan secara online, Sistem informasi rencana umum pengadaan, Data agregat kependudukan, SIM Aparatur Pemerintah Kelurahan, SIM perizinan Kulon Progo, SIM Geospasial Kulon Progo, Aspirasi Kulon Progo, JDIH Hukum dan Smat Report LPSE. Dari aplikasi layanan publik tersebut, empat website tidak bisa diakses diantaranya yaitu website sistem informasi rencana umum pengadaan, SIM

\footnotetext{
${ }^{1}$ https://kulonprogokab.go.id/
} 
perizinan Kulon Progo, Aspirasi Kulon Progo dan Smart Report LPSE. Sedangkan pada aplikasi layanan pemerintahan terdiri dari Rencanaku, Monevku, Sakipku, SIM Unit Layanan Pengadaan, SIM Surat, SIM Kepegawaian.Semua website pada aplikasi layanan pemerintah ini dapat diakses dengan baik. Hal tersebut juga mengingat bahwa infrastruktur teknologi informasi yang dimiliki Pemerintah kulon progo di nilai cukup baik.Hal ini terlihat dari ketersediaan komputer yang terkoneksi dengan jaringan lokal dan internasional serta peralatan pendukung lainnya (seperti printer dan scanner) yang digunakan untuk mendukung pelaksanaan tanggung jawab masing-masing departemen di seluruh SKPD di pemerintah kulon progo.

Dalam memberikan pelayanan E-Government secara online, pemerintah Kulon Progo juga memberikan inovasi dalam mendukung jalannya smart city dalam bentuk Quick Win. Salah satu programnya adalah Bumilku yang merupakan program unggulan Pemkab Kulonprogo. Bumilku mengandalkan informasi geospasial untuk menekan angka kematian ibu melahirkan tersebut merupakan bagian dari penerapan Smart City. Perwujudannya dalam bentuk aplikasi pemantauan kesehatan ibu hamil yang mengintegrasikan Nomor Induk Kependudukan (NIK) dan Geospasial. Kulonprogo sendiri masuk dalam Gerakan menuju 100 Smart City Tahap 2 dan menjadi program quick win yang dievaluasi secara berkala setiap enam bulan sekali oleh Kemkominfo ${ }^{2}$. Selain itu, pelembagaan pelaksanaan aplikasi BumilKu terintegrasi dengan Bidan Desa/Kelurahan, Puskesmas dan RSUD sehingga ibu hamil mendapatkan penanganan persalinan sampai di fasilitas kesehatan. Dampak perbandingan sebelum adanya aplikasi BumilKu dan setelah adanya aplikasi BumilKu untuk memberikan pelayanan kepada ibu hamil dirasakan efektif dan efesien oleh bidan, kader, maupun ibu hamil itu sendiri yang mendapatkan pelayanan (Prasetia, 2019). Dalam tahapan persyaratan untuk mendapatkan pelayanan hingga mendapatkan pelayanan aplikasi BumilKu memberikan kemudahan.

\footnotetext{
${ }^{2}$ https://aptika.kominfo.go.id/
} 
Banyaknya aplikasi pelayanan yang disediakan oleh pemerintah Kulon Progo menjadi suatu tantangan bagi Pemda untuk mengoptimalisasikan pelayanan tersebut untuk masyarakat agar dapat berjalan dengan efektif dan efisien. Pengembangan Aplikasi e-goverment di Kulon Progo bertujuan untuk meningkatkan efisiensi dan keterpaduan penyelenggaraan SPBE oleh Pemkab Kulon Progo dan perkembangan SPBE di Kabupaten Kulon Progo sendiri masih dalam proses pengintegrasian ${ }^{3}$. Secara umum Pemkab Kulonprogo masih kurang pada penggunaan aplikasi jika dibandingkan dengan Pemda-Pemda lain yang ada di Daerah Istimewa Yogyakarta. Dengan adanya pemeriksaan kinerja pendahuluan Sistem Pemerintahan Berbasis Elektronik (SPBE) Tahun 2019 dan Tahun 2020 Semester 1 yang telah dilaksanakan pada tahun 2020 lalu diharapkan dapat meningkatkan penggunaan aplikasi sehingga pelayanannya bisa tepat dan memudahkan dalam pengelolaan keuangan, sehingga bisa tepat waktu dan akurat.

Selain itu perlu dilakukan pendidikan dan pelatihan SDM di bidang teknologi informasi dan komunikasi yang terintegarsi di tingkat penyelenggara pemerintah daerah agar diperoleh pemahaman dan literacy yang menyeluruh dikalangan pegawai pemerintah daerah. Adanya diklat ini dapat dilaksanakan sendiri oleh masing-masing pemda yang lebih tahu kebutuhannya sendiri berkaitan dengan implementasi e-government. Sedangkan untuk tingkat masyarakat diperlukan strategi sosialisasi kepada masyarakat dengan beberapa tahapan seperti yang pertama,tahapan yang ditujukan untuk pemimpin karena pemimpin sangat memegang peranan dalam implementasi egovernment.Tahapan kedua,memberikan penekanan dalam sosialisasi egovernment di kalangan para pimpinan tentang manfaat yang bisa diperoleh dari penggunaan ICT dalam tata pemerintahan.Baik itu dari segi politis, ekonomi,produktivitas kerja pegawai dan juga image di mata masyarakat.Dan tahapan ketiga, memberikan brand awarness kepada para masyarakat luas tentang manfaat dan kegunaan bentuk-bentuk

\footnotetext{
${ }^{3}$ https://kulonprogokab.go.id/
} 
layanan dalam e-government. Mengingat beragamnya status sosial dan ekonomi masyarakat maka yang pertama diberikan penekanan sosialisasi adalah golongan masyarakat yang memiliki status sosial ekonomi menengah ke atas terlebih dahulu, karena mereka lebih dekat dengan teknologi internet dan konsep e-government.

\section{KESIMPULAN}

Implementasi e-government di kabupaten kulon progo bisa dikatakan belum efektif, seperti penjelasan yang ada di dalam pembahasan Pemkab Kulon progo kurang dalam penggunaan aplikasi dibanding pemda-pemda lain di DIY. Sesuai Perpres 95/ 2018 tentang SPBE, mengharuskan semua pemerintah kabupaten/kota menerapkan sistem aplikasi yang terintegrasi sebagai jalan tol sistem digital dalam menjalankan roda pemerintahan yang bersih serta pelayanan publik yang berkualitas dan terpercaya sehingga tercipta efisiensi, efektivitas dan akuntabilitas, guna menekan penyimpangan.Namun hal tersebut terhambat oleh penetrasi pasar hardware dan provider layanan jasa teknologi komunikasi dan informasi belum merata hingga daerah-daerah,sehingga bukan hanya masalah dalam suprastrukturnya saja tetapi dalam infrastrukturnya juga masih kurang memadai. Masalah tersebut juga diperparah dengan masih mahalnya sarana dan prasarana teknologi ICT. Untuk saat ini proses integrasi perencanaan dan keuangan menjadi hal yang paling sulit,karena sampai saat ini perubahan data dengan Badan Perencanaan Pembangunan Daerah masih dilakukan secara manual. Sedangkan sistem yang ada di badan tersebut dan Badan Keuangan dan Aset Daerah masih sendirisendiri,sehingga belum terintegrasi dengan baik.Pengembangan Aplikasi eGoverment di Kabupaten Kulon Progo bertujuan untuk meningkatkan efisiensi dan keterpaduan penyelenggaraan SPBE, namun perkembangan SPBE tersebut masih dalam proses pengintregasian. Dengan harapan kedepannya tidak banyak aplikasi namun terintregasi dan semuanya 
terintregasi tunggal tidak sendiri-sendiri dengan platform berbeda. Sehingga ke depan harapannya aplikasi tidak selalu banyak tapi bisa mengakses.

\section{DAFTAR PUSTAKA}

Alwafi Ridho Subarkah. (2018). pendahuluan. Nhk技研, 151(2), 10-17.

Indonesia, P. R. (2009). Undang-Undang RI No. 25 Tahun 2009 tentang Pelayanan Publik. Lembaran Negara RI Tahun 2009. Sekretariat Negara. Jakarta, $1-77$. http: / / pelayanan.jakarta.go.id/download/regulasi/undang-undangnomor-25-tahun-2009-tentang-pelayanan-publik.pdf

Kurniawan, R., \& Atmojo, M. E. (2020). Implementasi E-Government Kulon Progo: Inovasi Dinas Kesehatan Melalui Aplikasi BumilKU 2019. Jurnal Sosial Politik, $6(2)$ $142-156$. https://doi.org/10.22219/sospol.v6i2.11077

Nugraha, J. T. (2018). E-Government Dan Pelayanan Publik (Studi Tentang Elemen Sukses Pengembangan E-Government Di Pemerintah Kabupaten Sleman). Jurnal Komunikasi Dan Kajian Media, 2(1), 32-42.

Pratiwi, E., \& Muslihudin, M. (2018). Implementasi E-Goverment Sebagai Upaya Peningkatan Potensi Desa Di Desa Bumirejo Menggunakan Web Mobile. Technology Acceptance Model, 9(1), 22-29. www.stmikpringsewu.ac.id

Presiden, I., Indonesia, R., Dan, K., Nasional, S., E-government, P., \& Indonesia, P. R. (2003). Instruksi Presiden Republik Indonesia.

Sari, K. D. A., \& Winarno, W. A. (2012). Implementasi E-Goverment System Dalam Upaya Peningkatan Clean And Good Goverment Di Indonesia. Jeam, XI(1), 1-19.

Sosiawan, E. A. (2008). Tantangan Dan Hambatan Dalam Implementasi EGovernment Di Indonesia. Seminar Nasional Informatika, 2008(semnasIF), 99-108.

Vinet, L., \& Zhedanov, A. (2011). A “missing" family of classical orthogonal 
polynomials. Journal of Physics A: Mathematical and Theoretical, 44(8), 1689-1699. https://doi.org/10.1088/1751-8113/44/8/085201

Wulansari, A., \& Inayati, I. (2019). Faktor-faktor kematangan implementasi e-government yang berorientasi kepada masyarakat. Register: Jurnal Ilmiah Teknologi Sistem Informasi, 5(1), 24. https://doi.org/10.26594/register.v5i1.1288

Nur, E. (2014). Penerapan e-government publik pada setiap skpd berbasis pelayanan di kota palu. Jurnal Penelitian Komunikasi dan Opini Publik, $18(3), 123749$.

Simangunsong, J. (2010). Pengembangan E-government di Indonesia. Jurusan Magister Teknologi Informasi Fakultas Ilmu Komputer Universitas Indonesia Jakarta.

Somantri, O., \& Hasta, I. D. (2017). Implementasi e-Government Pada Kelurahan Pesurungan Lor Kota Tegal Berbasis Service Oriented Architecture (SOA). Jurnal Informatika: Jurnal Pengembangan IT, 2(1), 23-29.

Aprianty, D. R. (2016). Penerapan Kebijakan E-Government Dalam Peningkatan Mutu Pelayanan Publik Di Kantor Kecamatan Sambutan Kota Samarinda. Jurnal Ilmu Pemerintahan, 4(4), 1589-1602.

Nugraha, J. T. (2018). E-Government Dan Pelayanan Publik (Studi Tentang Elemen Sukses Pengembangan E-Government Di Pemerintah Kabupaten Sleman). Jurnal Komunikasi dan Kajian Media, 2(1), 32-42.

Napitupulu, D. (2015). Kajian Faktor Sukses Implementasi E-Government, Studi Kasus: Pemerintah Kota Bogor. Sisfo, 5.

Samsudin, I., \& Muslihudin, M. (2018). Implementasi web government dalam meningkatkan potensi produk unggulan desa berbasis android. JTKSI (Jurnal Teknologi Komputer dan Sistem Informasi), 1(2), 10-16.

Sari, K. D. A., \& Winarno, W. A. (2012). Implementasi E-Government System Dalam Upaya Peningkatan Clean And Good Governancedi Indonesia. 
Jurnal Ekonomi Akuntansi dan Manajemen, 11(1).

Sutanta, E., \& Mustofa, K. (2012). Kebutuhan Web Service Untuk Sinkronisasi Data Antar Sistem Informasi Dalam E-Gov Di Pemkab Bantul Yogyakarta. Jurnal Teknologi Informasi \& Komunikasi (Jurtik), $1(1)$.

Rachman, E. S., \& Noviyanto, B. (2017). Pemanfaatan e-government pada desa wonokarto untuk meningkatkan akurasi dan informasi potensi desa. Jurnal TAM (Technology Acceptance Model), 8(1), 45-50.

Sukarno, M. (2020). Implementasi Kebijakan E-Planning Pada Badan Perencanaan Pembangunan Daerah Kulon Progo. In Senaster" Seminar Nasional Riset Teknologi Terapan" (Vol. 1, No. 1).

Andiyansari, P. (2014). Studi pemberdayaan masyarakat pedesaan melalui teknologi informasi dan komunikasi. Jurnal Penelitian Pers Dan Komunikasi Pembangunan, 18(2), 117-130.

Sutanta, E., \& Ashari, A. (2012). Pemanfaatan Database Kependudukan Terdistribusi pada Ragam Aplikasi Sistem Informasi di Pemerintah Kabupaten/Kota. Sisfotenika, 2(1), 11-20.

Yunita, N. P. (2018). Kondisi Terkini Perkembangan e-Government di Indonesia: Praktik Pemerintah dan Persepsi Publik (Master's thesis, Universitas Islam Indonesia).

Sukirno, S. (2020). Dokter Pustaka Inovasi Layanan Masa Pademi Covid-19 Di Perpustakaan Fakultas Kedokteran, Kesehatan Masyarakat dan Keperawatan Universitas Gadjah Mada. Pustakaloka, 12(2), 171-185.

Sutanta, E., \& Wardoyo, R. (2012). Problem Perbedaan Kode Data dan Strategi Penyelesaiannya untuk Sinkronisasi Data Antar Database. Jurnal IPTEK-KOM, 14(2), 165-176.

Sumedang, S. S. A. (2019). Sleman Smart Regency: Synergic And Simultaneous Bureaucration Reform In Sleman Regency. International Journal Of Information, Business And Management, 11(2). 
Jurnal Caraka Prabu Vol.5 No. 1 Juni 2021 